\title{
Search on Innovation and Entrepreneurship Education Reform and Construction of College Students
}

\author{
Liang Kang \\ Chongqing College of Electronic Engineering \\ Chongqing, China \\ richard12@163.com
}

\begin{abstract}
Innovation and entrepreneurship education has become an inevitable trend of deepening the reform of higher education and the development. Innovation and entrepreneurship education is a major issue faced by the colleges and universities in the new period. Through the timely adjustment of educational ideas, constantly innovation and entrepreneurship education is combined into professional course teaching process, innovation and entrepreneurship education curriculum system is designed. The practice teaching base is established, the integration of teaching and professional practice is set up. They are the keys to improve the quality of the cultivation talents; optimization of innovation and entrepreneurship education, improve the teachers' quality of innovation and entrepreneurship education. These can promote the healthy development of innovation and entrepreneurship education.
\end{abstract}

Keywords-innovation and entrepreneurship; reform in education; construction Countermeasures; Cultivation process

\section{INTRODUCTION}

Strengthening innovation and entrepreneurship education and cultivating innovation and entrepreneurship talents are the strong choice to accelerate the reform of education in colleges and universities, and also the inevitable requirement to improve the employment quality of graduates. It is an accepted way to improve the quality of talent cultivation that recruiting lots of college students to participate in technical innovation activities. To give full play to the university technical innovation activities, the school should keep pace with The Times, based on the existing work test results, should not only be well combined with the school situation, but also meet the further requirements of the reform of innovation and entrepreneurship education, as well as shoulder the mission given by the era[1-3] Over the years, the university has changed the teaching mode of college practice through the project approval of innovation and entrepreneurship training program of college students, and has taught students to find problems and solve problems through training.

\section{THE REFORM OF INNOVATION AND ENTREPRENEURSHIP EDUCATION HAS BEGUN TO SHOW EARLY RESULTS}

A. Innovation and entrepreneurship education is integrated into the teaching process

Innovation and entrepreneurship education is comprehensive and systematic education. To master the basic theory, train the scientific method, especially form creative thinking, it is not enough only to teach in the classroom and repeat the job training, and it is necessary to carry out the comprehensive practice changing from the easy to the difficult. Before organizing innovation and entrepreneurship training, it is necessary to guide students to improve their professional learning and enrich their professional knowledge. In addition, it is also very important to strengthen students' innovative and entrepreneurial consciousness through various education ways since they started school. In order to find the right way to overcome obstacles in the process of combination, it is necessary to explore and enrich the innovation entrepreneurship education resources of various professional courses, make the idea and content of innovation and entrepreneurship education permeate into professional education, strengthen the innovation and entrepreneurship education in the process of imparting professional knowledge.

\section{B. Innovation and entrepreneurship teaching procedure is gradually standardized}

(1) Integrate innovation and entrepreneurship education into the talent cultivation program. In order to make innovation and entrepreneurship education through the process of professional education and quality education, in general, transfer the completed project to the technical innovation credits, actively explore and establish student innovation ability training system in the practice teaching link stipulated by the teaching plan, interact with the college students' innovative spirit and practice ability training and other series activities, promote the innovation of talent cultivation mode in school, so as to form a complete talent cultivation system.

(2) Set up specialized courses. Comprehensively update the knowledge system. Launch talent entrepreneurship education for students who are interested in starting a business, and set up entrepreneurship training class with a target. At the same time, set up relevant public elective courses to make college students 
master the basic skills and knowledge of entrepreneurship, have the basic quality and ability of entrepreneurship, to cultivate college students' entrepreneurial consciousness and innovative spirit, and inspire their entrepreneurial aspirations.

(3) Motivate students and teachers. Give students priority to participate in the innovation and entrepreneurship training program of college students, encourage students to apply for or participate in a "college student's innovation and entrepreneurship training program" during the study period. Projects that achieved the stage results can be used as the continuance of practical subject or graduation thesis (design) subject study stipulate by the teaching plan. Encourage teachers to transfer focus on the innovation and entrepreneurship training program of college students from existing sub project separated from scientific research projects in order to guide students to participate in the technical innovation activities. Encourage college departments to carry out curriculum innovation, strengthen teaching research, and actively promote teaching reform.

(4) Set reasonable innovation and entrepreneurship credits. Strengthen the innovation consciousness of college students, foster innovation and practice ability, promote innovation and entrepreneurship training of college students. Implement the flexible learning system, establish the result ratification credit of innovation and entrepreneurship training, encourage students to participate in training programs properly in combination with their interests, specialties and abilities in school and obtain the corresponding innovation practice credits according to the specific results of the training program, which should be included in the total credits to be earned.

\section{Innovation and entrepreneurship education is in line with practical teaching reform}

The college practice teaching is divided into two parts: inclass experiments and practice course. With in-class experiments transferred into innovative experiment project, according to the content and progress of theoretical teaching, students carry on training to foster their basic observation ability, thinking ability and practical ability to achieve the goal of consolidating theoretical knowledge by forming a college student's innovation and entrepreneurship training team to apply for the innovation and entrepreneurship program[4-5]. At the same time, the research laboratory is open to innovative entrepreneurial training programs of college students, which enables students' theoretical knowledge to be verified and applied in the actual production process, meanwhile broadens the knowledge of students, finally completes the practical teaching task of production internship, graduation internship or graduation design (thesis).

Study the similarities and differences of engineering, science and liberal arts education. In terms of practical teaching, college students' practice teaching is one of the important teaching links of higher education, is an important way to guide students to integrate theory with practice, cultivate students' comprehensive quality and innovation consciousness. In particular, the majors with strong the application and practicability have higher requirements on students' professional skills, and practical teaching has the special effect of other teaching methods in the cultivation of talents. The following four measures are recommended:

(1) Establish an effective mechanism.

Establish an effective combination mechanism of college student's scientific research training and graduation thesis (design), and explore new ways of teaching scientific research training courses. Encourage and support students, especially juniors, to go to the teachers' scientific research group and laboratory directly, and give special funds to teachers to strengthen scientific research training for college students.

(2) Implement the incentive scheme. Implement the incentive scheme for students writing theses or exchange these awards to realize the function of scientific research in the cultivation of undergraduate talents.

(3) Open experimental base. Establish an open experimental base of "innovation practice" and create conditions for the innovative talent cultivation. Students can go to the public and basic laboratories and participate in their innovative experiment activities. Students' practices and awards in the open experimental base of "innovation practice" are included in the student files and transcripts.

(4) Reform teaching contents. Reform experimental teaching contents, guide and encourage students to use social resources to carry out innovation practice, promote the integration of the production, learning and research.

\section{CONSTRUCTION OF INNOVATION AND ENTREPRENEURSHIP EDUCATION SYSTEM}

The idea of innovation and entrepreneurship education system construction is to determine innovation and entrepreneurship education target, stipulate education contents, implement specific measures and so on, based on the top level design and overall design of innovation and entrepreneurship education:

\section{A. Innovative talent cultivation mode}

In term of the advanced concept of innovation and entrepreneurship education, innovation and entrepreneurship education process is that the colleges, according to the development goal of talent cultivation and the law of social responsibility formation, exert purposeful, organized and planned impacts on the innovative spirit, entrepreneurial consciousness and entrepreneurial ability of the educated, to make them realize the transformation from knowledge to practice. Innovation and entrepreneurship education process is not only the process to combine the school education with selfeducation and going to the society, but also the process to combine innovation and entrepreneurship education with subject education, quality education and employment education. Only by establishing a coordinated, orderly and integrated innovation and entrepreneurship education system can the employment function of innovation and entrepreneurship education be developed to improve the employment rate of graduates.

Colleges are the best environment for innovation and entrepreneurship talent cultivation. The colleges' teaching mode, method, concept, plan, faculty, investment and establishment of innovation practice base will influence the 
quality of innovation and entrepreneurial talents. But what we are seeing is that the innovation and entrepreneurial talent produced by colleges are rare and, precious, which has a large gap with the number of "mass production" with large investment in the recruitment of new students. Innovation and entrepreneurship education should be consistent with the college students' talent cultivation system. In accordance with their own orientation, cultivation objectives and school characteristics, colleges should set up the course system independently, fully explore and enrich the innovation and entrepreneurship education resources of various specialized courses, strengthen innovation and entrepreneurship education in the process of imparting professional knowledge. To cultivate the "mass" of innovation and entrepreneurship talents, it is necessary to dialectically change the traditional teaching method and mode, draw the best and remove the worst, and gradually conduct the open cultivation combined with the advanced teaching concepts at home and abroad. Take focusing on students' independent thinking and ability to find and solve problems as the main line, regard students as the center, combine the in-class with out-of-class, science with humanity, teaching with research, so as to gradually form the unique innovative talent cultivation mode.

\section{B. Strengthening education content and cultivation method construction}

Set up the innovation and entrepreneurship program project, take the national, provincial and school-level college students' innovation and entrepreneurship training program projects as the start, to guide and encourage students to carry out interest research. Students manage independently, and members can participate in activities, exchange and learn from each other, which has the practicality that can't be given in class. Combining theory with practice by professional practice tasks, in this kind of environment the interactive communication can improve them in communication, and facilitate the construction of good professional learning atmosphere.

Construct the practical cultivation system composed of education curriculum, simulation training, competition and innovation and entrepreneurship project through the selection of excellent projects. Build an interdisciplinary college innovation and entrepreneurship team with strong integration of subjects, industry characteristics, strong feasibility and operability. Organize professional teachers to guide the college student's innovation and entrepreneurship team during the overall process. Hire enterprise experts that have a good understanding of the major technical requirements of the enterprise, the strong ability to solve practical problems, and profound theoretical knowledge to join the guidance. Promote innovation and entrepreneurship projects to the society and the government, through the implementation of college students' innovation and entrepreneurship preferential policies. Actively enlist the support of local governments, industry enterprises and multi-channel financing, to support and help students in various fields such as finance, technology, policy consultation, legal aid, etc.

Establish effective incentive and restraint mechanism of college students' innovative experiment, guide teachers to actively participate in college students' innovative experiment, encourage professors to guide the college students' innovative entrepreneurial training, put good and potential young teachers with better style of study to the first line of teaching, scientific research and development, encourage them to work in the enterprise to make them grow up as soon as possible. Actively recruit outstanding, successful entrepreneurs and foreign highlevel teachers to mentor student, make efforts to build a innovative experiment technical personnel team that is firm in politics, passionate in the job, relatively stable, and has good business, appropriate number of people, reasonable structure[67].

\section{Strengthen college student's innovation and entrepreneurship base construction}

(1) Innovation and entrepreneurship practice base construction. Build internship sites in the campus, balance, strengthen managing and actively develop paid service new way. Key laboratories, research bases and others are open to students. Support undergraduate students to participate in scientific research activities, strive for "three early enter", namely to early enter into topic, laboratory and team. Actively cooperate with the factory in scientific research and teaching, gradually build the stable training base outside campus based on the principle of mutual benefits, to combine college student's innovation and entrepreneurship training with the cultural quality education closely.

(2) Construction of “college student's entrepreneurship park". Construct the college student's entrepreneurship incubation base; provide research and management venues, communication networks and office facilities, systematic training and consultation services, as well as support for policy, financing, law and market, etc. for students with entrepreneurial intentions, so as to reduce the risks and costs of college students' entrepreneurship. The school aims to support the independent entrepreneurship of college students, take the construction of entrepreneurship incubation platform as one of the main forms, which sets policy theory research, entrepreneurship guidance training and integrated service as a whole, and provides all valuable resources for college students, to improve students' innovation practice ability and entrepreneurial consciousness, and truly realize "entrepreneurship expands employment"

\section{OPTIMIZE INNOVATION AND ENTREPRENEURSHIP EDUCATION WORKING MECHANISM}

Establish a sound mechanism; promote the overall optimization of college innovation and entrepreneurship education work, to make the work planned, organized, efficient and coordinated.

\section{A. Set up innovation and entrepreneurship education college}

Innovation and entrepreneurship education college popularizes innovative theories and teaches entrepreneurship courses for all students of the schools. It highlights course features, Combines innovation and entrepreneurship courses with college students' quality education, compulsory courses with elective courses, takes the basic knowledge of entrepreneurship as the basis, and the cultivation of entrepreneurship consciousness, spirit and ability as the core, is included in the professional compulsory courses on the basis of 
the maturity of elective courses, which has great significance to carry out innovation and entrepreneurial activities more effectively in the future.

Students should be trained in innovative and entrepreneurial knowledge from various angels. On the one hand, the college needs to recruit a number of students with the second degree to carry out the systemic innovation and entrepreneurship training and education. On the other hand, it should take innovation and entrepreneurship education into the other professional talent training program, integrate college students' career planning, employment and entrepreneurship courses and so on, set up the course in other college, and popularize entrepreneurship knowledge[8].

\section{B. Improve the quality of innovation and entrepreneurship education faculty}

(1) Build a mentor team. Build a high quality innovation and entrepreneurship mentor team combining full-time personnel with part-time personnel, the intramural with the extramural, which is composed of teachers with innovative consciousness, strong scientific research ability and abundant practical experience and extramural part-time teachers, such as schoolfellows, well-known scientists, entrepreneurs, venture capitalists and experts. Establish the effective incentive and restraint mechanism of college students' innovative experiment provide free guidance and advice in the whole process, and guide teachers to participate in college student's innovative experiment voluntarily.

(2) Strengthen training and assessment. The school should actively organize innovation and entrepreneurship guidance teachers to participate in all kinds of qualification training like entrepreneurship guidance and career planning. Select outstanding backbone teachers to go out for exchange, encourage them to work in social units such as enterprises and research institutes, to experience the entrepreneurial process, participate in innovation and entrepreneurship practice, and obtain first-hand information of enterprise management action, so as to improve teacher's innovation and entrepreneurship education ability. The teachers who have obtained the honors and achievements in the innovation and entrepreneurship guidance shall be given the preferential treatment on equal conditions in terms of teaching assessment, professional title evaluation, training and cultivation, and financial support.

\section{Strengthen self-management of innovative and entrepreneurial student teams}

Under the context of innovation and entrepreneurship team, it makes sense to encourage innovative and entrepreneurial student teams to compose dormitory members alone. Emphasizing students' participation in management, enhancing their responsibility consciousness, ownership consciousness and self-discipline consciousness, are conducive to further promoting the integration of teaching management and student management, which is a beneficial attempt of the long-effect mechanism to improve the quality of talent cultivation. The school integrates innovation and entrepreneurship education ideas into all links of student management, creates a activity atmosphere for university student's innovative experiments relying on document management, carries out activities aimed at cultivating students' concepts of entrepreneurship, innovation and creativity, holds various extracurricular scientific and technical work competition, so that the students' quality, management ability and organizational ability have been improved to a different degree, laying a solid foundation for them to start their own business after graduation.

\section{CONCLUSIONS}

In conclusion, the reform and construction of college student's innovation and entrepreneurship education can promote the university to establish new education concept. Highlight the importance of college student's innovation and entrepreneurship education, actively enlist the support of various parties and develop the work creatively. Deepen education teaching reform, transform the pattern of talent cultivation, strengthen ability training in innovation and entrepreneurship, and cultivate the high-level talents needed to adapt to the construction of the innovative country.

\section{ACKNOWLEDGMENT}

The research is supported by higher education research reform project of CQ (162070)

\section{REFERENCES}

[1] Zhao Y. Who's Afraid of the Big Bad Dragon: Why China Has the Best (and Worst) Education System in the World [M].

[2] Boulos A. Conceptualisation of constraints on creativity in teaching in higher education: Towards the possibility of challenging practices in an Irish university[D] , 2013.

[3] Lee M H. A tale of two cities: Comparing higher education policies and reforms in Hong Kong and Singapore[J]. Australian Journal of Education, 2002, 46(3): 255-286.

[4] Achieving quality learning in higher education[M]. Routledge, 2012.

[5] Drucker P. Innovation and entrepreneurship [M]. Routledge, 2014.

[6] Laukkanen M. Exploring alternative approaches in high-level entrepreneurship education: creating micromechanisms for endogenous regional growth [J]. Entrepreneurship \& Regional Development, 2000, 12(1): 25-47.

[7] Powell J J W, Bernhard N, Graf L. The emergent European model in skill formation comparing higher education and vocational training in the Bologna and Copenhagen processes [J].Sociology of Education, 2012, 85(3): 240-258.

[8] Boyd D. Why youth (heart) social network sites: The role of networked publics in teenage social life[J]. MacArthur foundation series on digital learning-Youth, identity, and digital media volume, 2007: 119-142. 